Marquette University

e-Publications@Marquette

8-1-2004

\title{
Is Globalization What It's Cracked Up to Be? Economic Freedom, Corruption, and Human Development
}

Syed H. Akhter

Marquette University, syed.akhter@marquette.edu

Accepted version. Journal of World Business, Vol. 39, No. 3 (August 2004): 283-295. DOI. (C) 2004 Elsevier. Used with permission.

NOTICE: this is the author's version of a work that was accepted for publication in Journal of World Business. Changes resulting from the publishing process, such as peer review, editing, corrections, structural formatting, and other quality control mechanisms may not be reflected in this document. Changes may have been made to this work since it was submitted for publication. A definitive version was subsequently published in Journal of World Business, VOL 39, ISSUE 3, August 2004, DOI. 


\title{
Is globalization what it's cracked up to be? Economic freedom, corruption, and human development
}

Author: Syed H. Akhter

\begin{abstract}
This paper examines the effect of economic globalization on human development and argues that the relation between economic globalization and human development is mediated by economic freedom and corruption. Findings suggest that economic globalization affects economic freedom positively and corruption negatively. In turn, economic freedom has a positive effect and corruption has a negative effect on human development. All relations are in the hypothesized directions and significant. Research, business, and public policy implications as well as directions for future research are presented.
\end{abstract}

The benefits of globalization are obvious: faster growth, higher standards of living, and new opportunities. Kofi Annan, 2001.

Globalization is an emotional word. It evokes strong reactions among exponents as well as opponents of globalization. While the former group equates globalization with higher living standards, greater transparency, and increased economic freedom, the latter associates it with economic exploitation, environmental degradation, and cultural homogenization. The controversies surrounding the effects of globalization reached a pinnacle when, during the World Trade Organization (WTO) meetings in Seattle, USA (November 29-December 3, 1999) and in Genoa, Italy (July 19-24, 2001), a variety of interest groups challenged the legitimacy of globalization and protested against what they considered to be its direct and collateral effects. The WTO considers the opposition to globalization a serious development. To avoid confrontation with the anti-globalization groups and also because of the reluctance of developed economies to host the WTO, the WTO held its recent meeting in Doha, Qatar (November 12-14, 2001).

The anti-globalization groups have been successful in reaching out to the general public. They have put together a coherent case for their position, drawing attention to issues such as the use of child labor in less developed economies, the indifference of pharmaceutical companies to the spread of AIDS and of the developed countries to the burden of third-world debt. These concerns about globalization have sparked heated debates among different segments of society. It is generally agreed that the nature and outcome of these debates will influence the progress of globalization. Globalization, as Weisbrot, Naiman, and Kim (2001) note, is not an inevitable outcome, but the result of the laborious process of rule making. 
Therefore, how and what trade and investment rules are formulated will be influenced by what people think of globalization and how they respond to this process.

The academic counterpart of the debate surrounding globalization is equally contentious. Some scholars claim that globalization has encouraged global pillage (Brecher \& Costello, 1994; Mander \& Goldsmith, 1996), undermined social cohesion (Greider, 1997), and eroded the sense of community and urban power structure (Knox, 1997; Mele, 1996). Furthermore, findings from other studies suggest that globalization:

- puts a downward pressure on wages in developed countries (Bronfenbrenner, 1996; Cline, 1996), widens the gap between the wages of skilled and unskilled workers (Amadeo, 1998; Wood, 1998), and exacerbates social tension by increasing conflict between groups over social organization (Rodrik, 1997a, 1997b).

- affects the distribution of income between the core and peripheral countries, with the latter experiencing an increase when transportation costs decline (Krugman \& Venables, 1995).

- engenders organizational downsizing (Sebbens, 2000) resulting in increasing unemployment (Agiomirgianakis \& Zervoyianni, 2001).

- affects peoples' health negatively by generating environmental degradation, inequality, poverty, and denial of human rights (Legge, 1998).

On the other side, it is argued that globalization, by increasing economic freedom and providing access to information, empowers people and makes them officious regulators of corporate activity, responsibility, and accountability (Balestrini, 2001). And while social science scholars have examined the impact of globalization on issues such as employment and wages, human rights and social tensions, they have paid insufficient attention to the effects of globalization on human development as it relates to life span, educational attainment, and purchasing power. Helleiner (2001), for example, notes that the most important impact of globalization is to promote the interest of human welfare and development.

A review of the international business literature suggests that existing studies have typically focused either on (a) the forces that result in globalization, or (b) the impact of globalization on competition and firm strategy. Sparse attention has been given to the impact of globalization on human development. There is a lack of scholarly research, especially empirical research that delineates the process through which globalization affects human development.

This paper attempts to fill this gap and add to the existing research in the following ways. First, scholars have used the term globalization in many contexts and given it varied meanings and interpretations (Macharzina, 1999). This study attempts to clarify the meaning of the 
construct by examining globalization at three levels: firm, industry, and country. The premise is that globalization is occurring at these three levels and therefore, the conceptual meaning of the construct becomes clear only when the context in which the term is used is specified. Second, existing research provides empirical measures of globalization at the firm and industry levels (Makhija, Kim, \& Williamson, 1997; Sullivan, 1994). This paper adds to this body of research by using a two-indicator measure of economic globalization at the country level. Third, existing studies have paid inadequate attention to the process through which globalization works out its effects. Rodrik (1997a, 1997b) draws attention to this situation by suggesting that we lack an understanding of how the "process" of globalization works. The present study presents a model that shows the process through which economic globalization at the country level affects human development, mediated by economic freedom and corruption. Finally, public policy and business implications in existing research are mostly based on qualitative case studies. This research provides empirical results on which public policies and business strategies can be formulated.

To achieve the above goals, this paper is divided into four sections. In the first section, we discuss globalization from conceptual and definitional perspectives and then cover issues related to the measurement of firm, industry, and country globalization. In the second section, we present the conceptual model and the hypotheses derived from the model. In the third section, we explain the statistical procedure, define and measure the exogenous and endogenous constructs, and present the findings. In the fourth section, we delineate managerial, theoretical, and public policy implications and provide directions for future research.

\section{Globalization is integration}

What is globalization? As a multidimensional construct, globalization carries a myriad of meanings (Neverdeen, 1994). The popular view mostly touches on the surface meaning and links globalization with terms such as McDonaldization and Coca-Colonization. These nominalizations convey a potent image of multinational firms driven by a common goal of expanding their business globally. The firms are generally viewed as aggressive competitors with matchless financial power and marketing savvy to overwhelm local businesses and dominate the world markets. In addition, as most of the popular multinationals are U.S.-based entities, globalization de facto has become a surrogate for Americanization. While these interpretations of globalization may be popular and appealing, they do not lend themselves to theoretical analyses.

In the academic literature, globalization has become synonymous with a borderless world (Ohmae, 1990), marketing of standardized products (Levitt, 1983), global village (Garci- 
Zamor \& Khator, 1994), and global management (Wilson, 1994). These varied interpretations indicate that the term has been adopted by different disciplines and given a discipline-specific perspective. In the international business literature, for example, scholars have examined globalization with respect to the drivers, process, degree, and effects of globalization (Bartlett \& Ghosal, 1989; Kobrin, 1991; Malnight, 1995; White \& Poynter, 1990). Furthermore, a review of the literature indicates that scholarly investigations of globalization have focused on three units of analysis-firm globalization, industry globalization and country globalization.

At the firm level, globalization has been conceptualized as the process through which firms move toward integrated network structures (Malnight, 1995). The idea of integration of operations across countries as firms globalize their operations is present in different international business research streams (Dunning, 1993). With regard to measuring globalization at the firm level, different indicators have been proposed. Sullivan (1994) proposes the following: foreign sales as a percentage of total sales, research and development intensity, advertising intensity, export sales as a percentage of total sales, and foreign profits as a percentage of total profits. However, Ramaswamy, Kroeck, and Renforth (1996) suggested the need for further refining the construct and measurement. In a recent study, Athanassiou and Nigh (2000) used only two items to measure firm internationalization, international sales as a percentage of total sales and international assets as a percentage of total assets, highlighting the integration aspect of a firm's global operations.

At the industry level, globalization is conceptualized as "a series of linked domestic industries in which rivals compete against each other on a truly worldwide basis" (Porter, 1986: 18). Morrison and Roth (1992: 399), likewise, characterize industry globalization as distinct competitive environments that are differentially interdependent. These and other conceptualizations of industry globalization, highlighting the integration and linkage aspects of industries across countries (Makhija et al., 1997), are reflected in the indicators used to measure the construct. Morrison and Roth (1992), for example, include the following indicators to measure industry globalization: level of international trade, intensity of international competition, worldwide product standardization, and presence of key competitors in all key international markets. Makhija et al. (1997), however, focus on only two aspects of industry globalization, international linkages and integration of value-added activities among countries. They measure international linkages as the proportion of international trade in relation to overall consumption within the industry and integration of value-added activities as the Grubel and Lloyd Index of Intra-industry Trade (Greenaway \& Milner, 1986; Grubel \& Lloyd, 1975).

At the country level, globalization is conceptualized as a multidimensional construct. For 
example, from the sociological perspective, globalization is defined as "a social process in which the constraints of geography on social and cultural arrangements recede;" and from the political perspective, globalization is viewed as a process that makes a nation-state “increasingly irrelevant” (Waters, 1995; Wood, 1997). From an economic perspective, globalization is defined as "the increasing internationalization of the production, distribution, and marketing of goods and services" (Harris, 1993: 755). Putting these different dimensions together, Holm and Sorenson (1995) view the meta-construct of globalization as the intensification of economic, social, and political interaction across national boundaries. The present study focuses on the economic dimension of globalization at the country level and defines it as the increasing cross-country integration of economic systems through trade and investments.

\section{Conceptual model and hypotheses}

The conceptual model presented in Plate 1 draws from the international business, political economy, and sociology research. The overall sequence of effects in the proposed model originates from economic globalization. Economic globalization is shown to affect both economic freedom and corruption. And these two constructs, in turn, affect human development.

Three features differentiate this study from prior studies. First, in contrast to studies that focus on the direct effects of economic globalization, this study argues that the influence of economic globalization on human development is mediated by corruption and economic freedom. Second, this study uses a two-indicator measure of economic globalization, incorporating both the international trade and investment components. International business research has emphasized the significance of these two aspects of international exchange for promoting economic integration across countries. Third, this study tests the conceptual relationships explicated in the model and answers the empirical questions involving the effects of economic globalization.

\subsection{Economic globalization and economic freedom}

Economic globalization is conceptualized as a process that results in increasing integration of a country's economy with the rest of the world. The integration of economic systems is driven by entrepreneurial initiatives-businesses looking for markets, resources, and efficiencies. When firms, motivated by economic and marketing goals, attempt to venture abroad, they often find that governmental controls, both at home and in host countries, impose restrictions on what they can and cannot do. These restrictions include tariff and nontariff barriers, exchange rate controls, and control over capital mobility. Together, these policies 
constrain the movement of goods and capital between countries. However, as globalization increases economic integration between countries, the capitalist class begins to apply pressure on the government for opening the economy (Harvey, Rail, \& Thibault, 1996). Businesses seek economic freedom to increase their involvement in the economy and facilitate international exchange, both inbound and outbound. There are, however, counterforces in every economy that oppose increasing economic freedom. The increase in economic freedom is seen as a potential threat to some sectors of the economy. These groups feel vulnerable to increasing global competition and, therefore, apply pressure on the government to keep the barriers in place. The success of these groups depends on the strength of their voting bloc and lobbying power. Governments are thus confronted with the dilemma of whether to keep existing trade and investment barriers in place or to enact new policies that would increase economic freedom. Panic (1998) argues that as the spread of global production and marketing activities results in integrating countries and making them more interdependent, it leaves governments no choice but to open their economies. Therefore, while governments will continue to protect some sectors of the economy, they will also attempt to increase economic freedom to facilitate international exchange. We, therefore, propose the following:

H1: Higher level of economic globalization is associated with higher level of economic freedom.

\subsection{Economic globalization and corruption}

In varying degrees, bureaucratic corruption is a fact of life everywhere. Defined as the abuse of public power and resources for private gains (Bardhan, 1997; Shleifer \& Vishny, 1993), corruption makes the exchange process less transparent, engendering behaviors that fulfill the self-interest of public officials and private actors. Abaroa (1999) note that bureaucrats and politicians, in pursuit of self interest, will engage in corrupt behavior if perceived benefits outweigh costs. In the U.S. the Foreign Corrupt Practice Act, passed in 1977, makes it a crime for U.S. firms to bribe a foreign official for business purposes. The issue of corruption has also been taken up by the Organization of American States (OAS), the Organization for Economic Cooperation and Development (OECD), and the World Trade Organization (WTO). Corruption occurs because of the monopoly power of the government over resources that the public needs (Alam, 1995; Farazmand, 1999). Globalization-induced corruption among elites has been noted by Gould (1991), Eisner (1995) and Jreisat (1997). These studies argue that trade and investments between countries put government officials and businesses in a relationship that is conducive to corruption. The popular press regularly reports on cases of corrupt behavior both

\section{Akhter}


in developing and developed economies. While this may be the case, the scope of corruption differs across countries. It could be argued that corruption in Nigeria and France are not at the same level. In Nigeria, for example, corruption occurs in an environment in which checks and balances of the governance system have failed. It manifests itself in all facets of public life. However, with greater integration of trade and investments, both domestic and international constituents will begin to exert pressure on the administrative structure to become more accountable and transparent, thus reducing the opportunities for corrupt behavior. Prakash and Hart (2000), for example, note that as the economy globalizes institutional impediments are removed. Furthermore, as a country develops its political institutions and ability to uphold laws through judicial processes, there will be a reduction in corruption. We, therefore, propose the following:

H2: Higher level of economic globalization is associated with lower level of corruption.

\subsection{Economic freedom and human development}

There is a vast literature on the effects of economic freedom on economic growth and income distribution (Ali, 1997; Ayal \& Georgios, 1998; Berggren, 1999; Dawson, 1998; Easton \& Walker, 1997). Scholarly evidence from this body of research supports the hypothesis of a positive linkage between economic freedom and economic growth and development. Building on this body of research, scholars have begun to examine the influence of economic freedom on human development. The interest in human development is partly in response to the concerns raised about the effects of increasing economic freedom on people's lives. Economic freedom, by providing protection of private property and by removing barriers that restrict transactions, taps into the entrepreneurial spirit of the people and encourages increased economic activities. The greater the involvement of people in economic activities, the more favorable will be the effects on human development. Goldsmith (1997), for example, suggests that the greater the economic rights of people the more they will contribute to human development. Esposto and Zaleski (1999) also note the positive influence of economic freedom on quality of life across nations. And Oi (1999) suggests that human capital develops as a result of economic freedom. We, therefore, propose the following:

H3: Higher level of economic freedom is associated with higher level of human development.

\subsection{Corruption and human development}


Among the different effects of corruption studied, economic growth and development have received considerable scholarly attention. Although some scholars claim that corruption and bribery can stimulate economic growth and development under certain circumstances (Brunetti, 1995; Nye, 1979), the overwhelming scholarly evidence supports the contrary view. That is, corruption has a negative influence on economic growth and development. Getz and Volkema (2001), for example, found an inverse relationship between corruption and GDP per capita. Findings also suggest that corruption adversely affects economic development by increasing distortionary effects (Goudie \& Stasavage, 1997), encouraging collusion (Alam, 1990), reducing incentives to invest (Mauro, 1995), and imposing costs on society (RoseAckerman, 1999). As economic development suffers due to corruption, it could be argued that human development, in general, will also be adversely affected. Jazairy et al. (1992), for example, suggest that corrupt politicians and rent-seeking public bureaucracies can perpetuate poverty. We, therefore, propose the following:

H4: Higher level of corruption is associated with lower level of human development.

\section{Method}

\subsection{Statistical procedure}

The hypothesized relations between exogenous and endogenous constructs, shown in Plate 1 , were tested using a covariance matrix in a model using a full-information maximum likelihood approach. The use of a covariance matrix is recommended for the statistical procedure in the LISREL 8.3 program (Joreskog \& Sorbom, 1996). The statistical procedure involves two interrelated models, a structural model and a measurement model. The structural equation model specified the hypothesized relations between the exogenous construct, economic globalization, and the three endogenous constructs. The measurement model specified the hypothesized relations between the reflective indicators and their respective constructs. The three endogenous constructs were economic freedom, corruption, and human development. The loading for each of these three constructs was fixed to one. Fixing the single indicator of each construct to one indicates that the construct is measured on the same measurement scale as the corresponding indicator (Hayduk, 1988).

\subsection{Data}

Data for this study were obtained from published sources such as The United Nations, The World Bank, Tranparency International, and Cato Institute. Data provided by these organizations are widely used by academicians to test hypotheses, by government officials to 
develop public policies, and by executives to make international business decisions. The use of secondary data collected by different agencies, however, involves two common problems: incomplete data and varying number of countries on which the data are available. This forces the sample size to correspond to the data set with the lowest number of countries with further reduction in sample size coming from missing values. For example, Transparency International provides data on corruption for 85 countries, compared to economic freedom data on 109 countries provided by Cato Institute for 1998. As Transparency International covered the lowest number of countries, their list of 85 countries formed the sample size for this study. Furthermore, a listwise deletion procedure was used to develop the covariance matrix, which resulted in 75 countries with complete data (see Appendix A for the list of countries). Furthermore, a time series analysis was not considered appropriate because the index for the same construct is not comparable across years. Transparency International, for example, has used different methods to collect data in different years, making it difficult to compare data longitudinally. A structural equation model was therefore tested on 1998 cross-section data. Considering that the model was tested on 75 countries, the generalizability of findings can be considered restricted. However, it is important to note that the 75 countries included in the analysis come from all of the four income groups (high income, upper middle income, lower middle income, and low income countries) as defined by the World Bank. Furthermore, the countries included in the study cover approximately $85 \%$ of the world's population and $95 \%$ of the world's GDP (see Appendix B for data sources and descriptions).

\subsection{Exogenous construct-economic globalization (EG)}

As economic globalization involves the integration of economic systems, a common indicator of this construct used in the literature is the ratio of exports to GDP. A high ratio indicates not only a higher degree of dependence on foreign markets for a country's products but also a higher level of integration. However, by itself, the exports to GDP ratio is considered inadequate because of its exclusive focus on the trade aspect of globalization. As both exports and foreign direct investments (FDI) are the main routes of accessing resources, markets, and efficiencies, scholars recommend the use of both exports and FDI to measure economic globalization (Julius, 1990). Through FDI, firms are able to transfer capital, managerial knowhow, technologies, and products across country markets, bringing about a greater integration of economies. Thus, to measure the level of economic globalization these two variables (exports and FDI) are expressed as a ratio of GDP, with higher ratios indicating higher levels of economic globalization. Business scholars rely on multilateral agencies such as the World Bank and the United Nations for macro data such as GDP and FDI. Data from these sources are 
regularly used by social science scholars, public policy makers, and business executives.

\subsection{Endogenous constructs}

\subsubsection{Economic freedom (EF)}

Economic freedom was measured by the Economic Freedom of the World's Trade Openness Index. The index is the result of a series of conferences organized by Michael Walker, the Executive Director of the Fraser Institute of Vancouver, British Columbia, and Nobel laureate Milton Friedman to define and measure economic freedom. The index is based on four components: tariff rates, black market exchange rate premium, restrictions on capital movements, and the actual size of the trade sector compared to the expected size. The rating on tariffs incorporates taxes on international trade as a share of the trade sector, mean tariff rates, and standard deviation of tariffs. Countries with smaller values are assigned higher ratings. The size of the black-market exchange rate premium indicates the restrictiveness of the exchange rate controls. Countries with lower black-market premium are assigned higher ratings. Capital market restrictions reduce the volume of international exchange. Countries with lower restrictions are assigned higher ratings. For the trade component, a country's actual trade sector is compared with the expected size. That is, how much should a country trade given its population, geographical size, miles of coastline, and location relative to concentration of world demand. The larger the actual trade relative to the expected trade, the higher the ratings. The ratings for each of these four components are averaged to derive the index, ranging from 0 to 10. Higher ratings are indicative of greater economic freedom. The index is now being used by scholars from different disciplines. An extensive list of articles using the index of Economic Freedom can be found at www.freetheworld.com/papers.html.

\subsubsection{Corruption (CO)}

As a construct, corruption is not easy to quantify because most of it is clandestine, being illegal in every country. An objective measure of corruption would require that both the bribe giver and bribe taker agree to provide the information or that the actual act of bribery is recorded surreptitiously. Neither of these two scenarios would provide comprehensive and reliable data on corruption. It is highly unlikely that people would agree to provide such information without the fear of reprisals or embarrassment, just as it would be highly impractical to surreptitiously record every act of corrupt behavior. Academics, therefore, are using perception-based, subjective data. Corruption was measured by the Transparency International's ( $\mathrm{TI}$ ) corruption index. The index ranks countries in terms of the degree to which corruption is perceived to exist among public officials and politicians. It is a composite index that draws on 14 different polls and surveys from seven independent institutions, carried out among business people and country 
analysts, including surveys of residents, both local and expatriate. The corruption index is a continuous scale, ranging from 0 to 10 , with 0 representing a highly clean state. To facilitate interpretation, the score was subtracted from 10 to indicate higher corruption for higher scores. The TI corruption index has been used in several papers involving international business, economic development, and ethics (Getz \& Volkema, 2001; Heidenheimer, 1996; Husted, 1999; Volkema, 1997). Lancaster and Montinola (1997), note that by combining several measures of political corruption for each country, both the operationalization and measurement of Tl's index become robust. In particular, they note that the combination of multiple surveys addresses issues related to reliability and validity and, therefore, the index will open new avenues in research on corruption.

\subsubsection{Human development (HD)}

Human development was measured by the United Nation's human development index, which is a composite measure of life expectancy, educational attainment, and purchasing power. The index is an objective measure of human condition. Higher life expectancy is indicative of better nutrition, medical care, and a cleaner environment. Educational attainment shows people's ability to improve their living conditions and contribute positively to the social system. Real purchasing power reflects the means people have to satisfy needs for products and services. Thus, the human development index can be considered reflective of an environment which helps people develop their full potential and lead productive lives.

\subsection{Findings}

The model shown in Plate 1 is assessed using a full-information method. It examines the effects of economic globalization on human development, mediated by economic freedom and corruption. The overall fit of the structural model was determined by examining the $\chi^{2}$ value. The $\chi^{2}$ value of 6.52 with four degrees of freedom has a statistical significance level of 0.16 . This statistic shows support for believing that the differences between the actual and predicted matrices are nonsignificant, indicating a good fit between the hypothesized model and data. Furthermore, the Goodness-of-Fit Index (0.96) and adjusted Goodness-of-Fit Index (0.86) are both higher than the recommended level. Together, they suggest that the results are an acceptable representation of the hypothesized model. The Root Mean Square Residual (0.0078), which is the square root of the mean of the squared residuals, also shows a good fit. Furthermore, the Normed Fit Index of 0.94 shows that the model has explanatory power. Overall, the various fit indices lend support to the hypothesized model, showing the effects of economic globalization on human development, mediated by economic freedom and corruption.

The coefficient estimates for the various paths and the associated $t$-values are provided

\section{Akhter}


in Table 1. The structural coefficients are significant and in the hypothesized directions. The effect of economic globalization on economic freedom, $\xi_{1}$ on $\eta_{1}$, is positive and significant; the effect of economic globalization on corruption, $\xi_{1}$ on, $\eta_{2}$ is negative and significant. The effect of economic freedom on human development, $\eta_{1}$ on $\eta_{3}$, is positive and significant; the effect of corruption on human development, $\eta_{2}$ on $\eta_{3}$, is negative and significant (see Table 1). The model accounts for $86 \%$ of the variance in economic freedom $\left(\eta_{1}\right), 28 \%$ of the variance in corruption $\left(\eta_{2}\right)$, and $54 \%$ of the variance in human development $\left(\eta_{3}\right)$. Table 1 also shows the total effects of globalization on human development. The total effect of globalization on human development is positive and significant.

\section{Discussion and implications}

The goal of the paper was to model the influence of economic globalization on human development, mediated by economic freedom and corruption. The findings suggest that the total effect of economic globalization on human development is positive and significant. The model presented in this paper is parsimonious and explains a large percentage of variance in the three endogenous constructs: economic freedom, corruption, and human development. We present the implications of the findings next.

The selection of a country market is an important decision that firms have to make in internationalizing their operations. When expanding their operations, firms seek to enter country markets where they can achieve organizational goals and also increase the rate of return on their investments. The choice of a country market can be facilitated by examining the level of economic globalization, which is shown to have a positive influence on economic freedom. A higher level of economic freedom suggests greater opportunities for business transactions combined with the legal protection of property. Furthermore, as a higher level of economic freedom results in a higher standard of living, the demand for products and services, both domestically produced and imported, will be higher. Together, an understanding of these interactions would aid managerial decision making that involves the selection of country markets.

Economic globalization is also shown to influence human development through corruption. The decrease in corruption with increasing economic globalization and the increase in human development with decreasing corruption show the beneficial effects that comes from economic globalization. Among the adverse effects of corruption are an increase in environmental uncertainty and a decrease in transparency in the business environment. These conditions distort market forces and reduce efficiency in the allocation of resources, making a country market less attractive. The implication of the findings is not that multinationals will totally 
refrain from going to countries where corruption is high, but that they will not operate there at the same level as they would in countries where corruption is low. This situation can have adverse effects on human development in countries where corruption is high. Overall, economic globalization, by bringing about greater integration of a country's economic system with the trading partners and by enhancing human development, improves the attractiveness of a country market.

A visible difference appears across countries in the success they have achieved in creating an environment that supports private initiatives. Public policies, designed to create a conducive exchange environment, can be instrumental in generating confidence among local entrepreneurs and foreign businesses. Although increasing exports and FDI encourages economic freedom, it will be beneficial for governments to be proactive in instituting policies that result in greater economic integration. Developing and implementing policies to increase the inflow of FDI can have beneficial side effects on the economy. FDI is important not only for the inflow of capital, but also for the technology and managerial expertise it brings into a social system. New technology and managerial know-how will encourage innovations in the local economy that, in turn, will help improve the business environment in the country. Policies that encourage higher economic integration will thus translate into increased human development.

In summary, as economic globalization leads to greater transparency and economic freedom, societies avail of opportunities to achieve a higher standard of living. This is a promising aspect of globalization. As more-globalized economies are shown to fare better than less-globalized economies, public policies in less globalized economies will need to create conditions for increasing economic globalization. However, the pursuit of globalization needs to be tempered with social concerns. Globalization occurs in a social system and on this road to globalization there will be winners and losers. Research demonstrates that some segments of the society are not well equipped to deal with the challenges of globalization. Thus, from a policy perspective, the safeguarding of groups most vulnerable to market forces should be an integral part of policy agendas. As Rodrik (1997a, 1997b) argues the need for social insurance increases as global integration increases.

With regard to directions for future research, we suggest the following. As there are different dimensions of globalization and human development, future studies can explore the effects of social, political, and technological globalization on objective as well as subjective human development. Furthermore, in examining these effects, scholars can select either regions or cities as units of analysis. Krugman's (1992) and Rauch's (1991) work on geography and trade and urban economics and trade provide appropriate theoretical structures. These 
links need to be explored in future studies. Another issue that warrants scholarly attention addresses the measurement of the meta construct globalization. While scholars have distinguished between cultural, political, and technological globalization, much of the research in this area is qualitative and case-based. Future research can focus on developing theoretically grounded and empirically useful measures of these concepts to study their antecedents and consequences.

\section{Conclusion}

The debate on globalization is expected to continue because the socioeconomic and political implications are pervasive and profound. Every time the World Trade Organization, International Monetary Fund, or World Bank holds a meeting, groups opposed to globalization congregate at the same venue to voice their concerns. This face-off has brought the issue of globalization to the forefront in different parts of the world. While world leaders are seeking ways to develop a consensus on globalization, the antiglobalization groups are recruiting sympathizers to organize a more vociferous opposition. The process and outcome of these altercations will determine both the scope and speed of globalization. Therefore, it is important to inform these discussions with empirical findings. This study is an attempt to achieve this goal.

\section{References}

Abaroa, R. (1999). Towards 2005: Profits, people and the future of the regulatory state in the free market model. Law and Policy in International Business, 30: 131-138.

Agiomirgianakis, G., \& Zervoyinanni, A. (2001). Globalization of labor markets and macroeconomic equilibrium. International Review of Economics \& Finance, 10(2): 109_ 133.

Alam, M. S. (1990). Some economic costs of corruption in LDC's. Journal of Development Studies, 27(1): 89-97.

Alam, M. S. (1995). A theory of limits on corruption and some applications. Kyklos, 48: 419-435.

Ali, A. M. (1997). Economic freedom, democracy and growth. Journal of Private Enterprise, 13(Fall): 1020.

Amadeo, E. (1998). International trade, outsourcing and labour: A view from the developing countries. In R. Kozul-Wright \& R. Rowthorn (Eds.), Transnational corporations and the global economy (pp. 373-400). St. Martins Press, Inc.

Athanassiou, N., \& Nigh, D. (2000). Internationalization, tacit knowledge and the top management teams of MNCs. Journal of International Business Studies, 31(3): 471-487. 
Ayal, E. B., \& Georgios, K. (1998). Components of economic freedom and growth: An empirical study. Journal of Developing Areas, 32(Spring): 327-338.

Balestrini, P. P. (2001). Amidst the digital economy, philanthropy in business as a source of competitive advantage. Journal of International Marketing and Marketing Research, 26(1 February): 13-34.

Bardhan, P. (1997). The role of governance in economic development: A political economy approach. Paris: Organization for Economic Cooperation and Development.

Bartlett, C. A., \& Ghosal, S. (1989). Managing across borders: The transnational solution. Boston, MA: Harvard Business School Press.

Berggren, N. (1999, September). Economic freedom and equality: Friends or foes. Public Choice, 100: 203-223.

Brecher, J., \& Costello, T. (1994). Global village or global pillage: Economic reconstruction from the bottom up. Boston, MA: South End Press.

Bronfenbrenner, K. (1996). Final report: The effects of plant closing or threat of plant closing on the right of workers to organize. Cornell University Press.

Brunetti, A. (1995). Political variables in cross-country growth analysis (Working Paper). Cambridge, MA: Harvard University.

Cline, W. (1996). Trade and income distribution (p. 234).

Dawson, J. W. (1998, October). Institutions, investment, and growth: New cross-country and panel data evidence. Economic Inquiry, 36: 603-619.

Dunning, J. (1993). National enterprises and the global economy. Addison Wesley Publishing Company.

Easton, S. T., \& Walker, M. A. (1997, May 2). Income, growth, and economic freedom. American Economic Review, 87: 328-332.

Eisner, M. (1995). The state in the American political economy. Englewood Cliffs, NJ: Prentice Hall.

Esposto, A., \& Zaleski, P. (1999). Economic freedom and the quality of life. Constitutional Political Economy, 10: 185-197.

Farazmand, A. (1999). Globalization and public administration. Public Administration Review, 59(6): 509-522.

Garci-Zamor, J., \& Khator, R. (1994). Public administration in the global village. Westport, CT: Praeger.

Getz, K. A., \& Volkema, R. J. (2001). Culture, perceived corruption, and economics. Business \& Society, 4O(1): 7-30. 
Goldsmith, A. A. (1997). Economic rights and government in developing countries: Crossnational evidence on growth and development. Studies in Comparative International Development, 32(2): 29-44.

Goudie, A. W., \& Stasavage, D. (1997). Corruption: The issues. Paris: Organization for Economic Cooperation and Development.

Gould, D. (1991). Administrative corruption: Incidence, causes, and remedial strategies. In A. Farazmand (Ed.), Handbook of comparative and development public administration (pp. 467-484). New York: Marcel Dekker.

Greenaway, D., \& Milner, C. (1986). The economics of intra-industry trade. Boston: Basil Blackwell.

Greider, W. (1997). One world, ready or not-The manic logic of global capitalism. New York, NY: Simon \& Schuster.

Grubel, H. G., \& Lloyd, P. J. (1975). Intra industry trade. London: Macmillan.

Harris, R. G. (1993, November). Globalization, trade, and income. Canadian Journal of Economics, 4: 755-776.

Harvey, J., Rail, G., \& Thibault, L. (1996). Globalization and sport: Sketching a theoretical model for empirical analyses. Journal of Sport and Social Issues, 20(3): 258-270.

Hayduk, L. A. (1988). Structural equation modeling with LISREL: Essentials and advances. Baltimore: John Hopkins University Press.

Heidenheimer, A. J. (1996). The topography of corruption: Explorations in a comparative perspective. International Social Science Journal, 158(3): 337-347.

Helleiner, G. K. (2001). Markets, politics and globalization: Can the global economy be civilized? Journal of Human Development, 2(1): 27-46.

Holm, H., \& Sorenson, G. (1995). Whose world order? Uneven globalization and the end of cold war. Boulder, Colorado: Westview Press.

Husted, B. W. (1999). Wealth, culture, and corruption. Journal of International Business Studies, 30(2): 339-360.

Jazairy, I., Alamgir, M., \& Panuccio, T. (1992). The state of world rural poverty: An enquiry into the causes and consequences. New York: University Press.

Joreskog, K., \& Sorbom, D. (1996). LISREL 8: User's reference guide. Scientific Software International.

Jreisat, J. (1997). Politics without process: Administering development in the Arab world. Boulder, CO: Lynne Reinner.

Julius, D. (1990). Global companies and public policy. New York: Council of Foreign Relations. 
Kobrin, S. J. (1991). An empirical analysis of the determinants of global integration. Strategic Management Journal, 12: 17-31.

Knox, P. (1997, May). Globalization and urban economic change. The Annals of the American Academy of Political and Social Science, 551:17-27.

Krugman, P. (1992). Geography and international trade. Cambridge, MA: MIT Press.

Krugman, P., \& Venables, A. J. (1995, November 4). Globalization and the inequality of nations. The Quarterly Journal of Economics, 110: 857-881.

Lancaster, T. D., \& Montinola, G. R. (1997). Toward a methodology for the comparative study of political corruption. Crime, Law \& Social Change, 27: 185-206.

Legge, D. (1998). Globalisation: What does 'intersectoral collaboration' mean. Australian and New Zealand Journal of Public Health, 22(1 February): 158-163.

Levitt, T. (1983, May-June). The globalization of markets. Harvard Business Review, 92-102.

Macharzina, K. (1999). Limits of globalization. Management International Review, 39(2): 99-102.

Makhija, M. V., Kim, K., \& Williamson, S. D. (1997). Measuring globalization of industries using a national industry approach: Empirical evidence across five countries and over time. Journal of International Business Studies, Fourth Quarter, 679-710.

Malnight, T. W. (1995). Globalization of an ethnocentric firm: An evolutionary perspective. Strategic Management Journal, 16: 119-141.

Mander, J. \& Goldsmith, E. (Eds.), (1996). The case against the global economy and for a return toward local. San Francisco, CA: Sierra Club Books.

Mauro, P. (1995). Corruption and growth. Quarterly Journal of Economics, 109: 681-712.

Mele, C. (1996). Globalization, culture, and neighborhood change: Reinventing the lower east side of New York. Urban Affairs Review, 32(1): 3-22.

Morrison, A., \& Roth, K. (1992). A taxonomy of business-level strategies in global industries. Strategic Management Journal, 13(6): 399-418.

Neverdeen, P. J. (1994). Globalization as hybridization. International Sociology, 9: 161-184. Nye, J. S. (1979). Corruption and political development: A cost-benefit analysis. In M. Ekpo (Ed.), Bureaucratic corruption in sub-Saharan Africa: Causes, consequences, and controls (pp. 57-79). Washington, D.C.: University Press of America.

Ohmae, K. (1990). The borderless world. London: Harper-Collins.

Oi, W. (1999). The hearty and cheery state. Contemporary Economic Policy, 17(1): 138-146.

Panic, M. (1998). Transnational corporations and the nation state. In R. Kozul-Wright, \& R. Rowthorn (Eds.), Transnational corporations and the global economy. Macmillan Press, Ltd. 
Porter, M. E. (1986). Competition in global industries: A conceptual framework. In M. Porter (Ed.), Competition in global industries. Boston: Harvard Business School Press.

Prakash, A., \& Hart, J. (2000). Indicators of economic integration. Global Governance, 6:95-114. Ramaswamy, K., Kroeck, G., \& Renforth, W. (1996). Measuring the degree of internationalization of a firm: A comment. Journal of International Business Studies, First Quarter, 167-177.

Rauch, J. E. (1991). Comparative advantage, geographic advantage and the volume of trade. Economic Journal, 101: 1230-1244.

Rodrik, D. (1997a). Has globalization gone too far? Washington, D.C.: Institute for International Economics.

Rodrik, D. (1997b, Spring). Has globalization gone too far. California Management Review, 39(3): 29-53.

Rose-Ackerman, S. (1999). Corruption and government: Causes, consequences, and reform. Cambridge, UK: Cambridge University Press.

Sebbens, T. D. (2000). Rising tides, leaky boats: The influence of downsizing on wage levels. New Zealand Journal of Industrial Relations, 25(2 June): 119-150.

Shleifer, A., \& Vishny, R. (1993). Corruption. Quarterly Journal of Economics, 108: 559-617.

Sullivan, D. (1994). Measuring the degree of internationalization of a firm. Journal of International Business Studies, 2nd Quarter, 325-342.

Volkema, R. J. (1997). A comparison of perceptions of ethical negotiation behavior in Mexico and the United States. The International Journal of Conflict Management, 9(3): 218-233.

Waters, M. (1995). Globalization. New York: Routledge.

Weisbrot, M., Naiman, R., \& Kim, J. (2001). The emperor has no growth: Declining economic growth rates in the era of globalization. Center for Economic and Policy Research.

White, R. E., \& Poynter, T. A. (1990). Organizing for worldwide advantage, In C. Bartlett, Y. Doz, \& G. Hedlund (Eds.), Managing global firms (pp. 95-113). New York: Routledge.

Wilson, D. (1994). Bureaucracy in international organizations: Building capacity and credibility in a newly interdependent world. In A. Farazmand (Ed.), Handbook of bureaucracy (pp. 305-318). New York: Marcel Dekker.

Wood, A. (1998, September). Globalisation and the rise of labor market inequalities. The Economic Journal, 108: 1463- 1482.

Wood, E. M. (1997, November). A note on Du Boff and Herman. Monthly Review.

\section{Notes}

${ }^{*}$ College of Business, Marquette University, P.O. Box 1881, Milwaukee, WI 53201-1881,

18 Akhter 
USA . Tel.: p1 414288 3309. E-mail address: syed.akhter@marquette.edu (S.H. Akhter).

\section{Appendix}

Figure 1

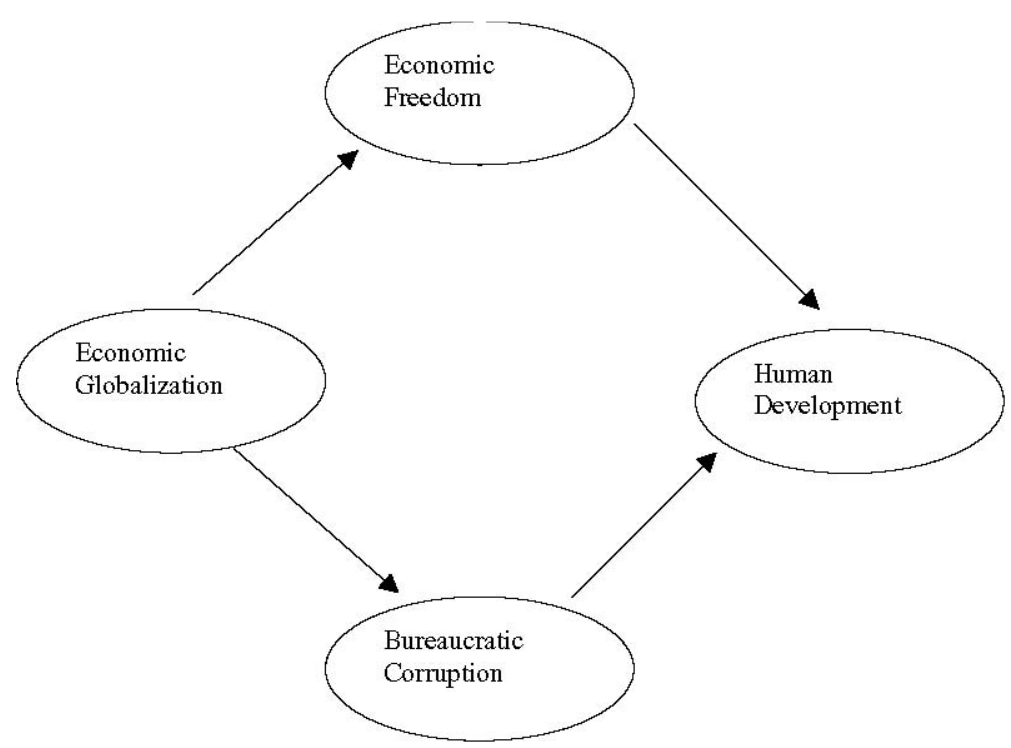

Plate 1. Conceptual model. 
Table 1

Testing the model relationships (Plate 1) structural equation coefficients

\begin{tabular}{|c|c|c|c|c|}
\hline Sign & From & To & Relationship estimate & $t$-value \\
\hline$(+)$ & $\mathrm{EG}\left(\xi_{1}\right) \rightarrow$ & $\mathrm{EF}\left(\eta_{1}\right)$ & 10.21 & 2.99 \\
\hline$(-)$ & $\mathrm{EG}\left(\xi_{1}\right) \rightarrow$ & $\mathrm{CO}\left(\eta_{2}\right)$ & -11.75 & -3.30 \\
\hline$(+)$ & $\mathrm{EF}\left(\eta_{1}\right) \rightarrow$ & $\mathrm{HD}\left(\eta_{3}\right)$ & 0.04 & 3.84 \\
\hline$(-)$ & $\mathrm{CO}\left(\eta_{2}\right) \rightarrow$ & $\mathrm{HD}\left(\eta_{3}\right)$ & -0.03 & -5.60 \\
\hline \multicolumn{5}{|l|}{ Goodness-of-Fit Statistics } \\
\hline Chi-Square (d.f.) & & & \multicolumn{2}{|c|}{$\begin{array}{l}6.52(p=0.16), 4 \text { degrees of } \\
\text { freedom }\end{array}$} \\
\hline Goodness-of-Fit Index & & & 0.96 & \\
\hline $\begin{array}{l}\text { Adjusted Goodness-of-Fit } \\
\text { Index }\end{array}$ & & & 0.86 & \\
\hline $\begin{array}{l}\text { Root Mean Square } \\
\text { Residual }\end{array}$ & & & 0.0078 & \\
\hline Normed Fit Index & & & 0.94 & \\
\hline \multicolumn{5}{|c|}{ Total effects of globalization on human development } \\
\hline$(+)$ & $\mathrm{EG}\left(\xi_{1}\right) \rightarrow$ & $\mathrm{HD}\left(\eta_{3}\right)$ & 0.79 & 3.29 \\
\hline
\end{tabular}

EG: economic globalization; EF: economic freedom; CO: corruption; HD: human development. 
Table 2

List of countries

\begin{tabular}{|l|l|l|}
\hline Argentina & Guatemala & Norway \\
\hline Australia & Honduras & Pakistan \\
\hline Austria & Hong Kong & Paraguay \\
\hline Belgium & Hungary & Peru \\
\hline Bolivia & Iceland & Philippines \\
\hline Botswana & India & Poland \\
\hline Brazil & Indonesia & Portugal \\
\hline Bulgaria & Ireland & Romania \\
\hline Cameroon & Israel & Russia \\
\hline Canada & Italy & Senegal \\
\hline Chile & Jamaica & Sloval Rep. \\
\hline China & Japan & South Africa \\
\hline Columbia & Jordan & Spain \\
\hline Costa Rica & Kenya & Sweden \\
\hline Cote d'Ivoire & Korea (South) & Switzerland \\
\hline Czech Republic & Latvia & Thailand \\
\hline Denmark & Malawi & Tunisia \\
\hline Ecuador & Malaysia & Turkey \\
\hline Egypt & Mauritius & Ukraine \\
\hline El Salvador & Mexico & U.K. \\
\hline Estonia & Morocco & U.S.A. \\
\hline Finland & Namibia & Uruguay \\
\hline France & Netherlands & Venezuela \\
\hline Germany & New Zealand & Zambia \\
\hline Greece & Nicaragua & Zimbabwe \\
\hline
\end{tabular}




\section{Table 3}

\section{Data sources and descriptions (all data for 1998)}

\begin{tabular}{|c|c|}
\hline Constructs & Source and description \\
\hline $\begin{array}{l}\text { Economic } \\
\text { globalization }\end{array}$ & $\begin{array}{l}\text { Two ratio variables, exports of goods and services as a share of GDP } \\
\text { (XGDP) and foreign direct investments as a share of GDP, (FDIGDP) } \\
\text { indicated economic globalization Foreign direct investment (FDI) is defined } \\
\text { as an investment involving a long-term relationship and reflecting a lasting } \\
\text { interest and control of a resident entity in one economy in an enterprise } \\
\text { resident in an economy other than that of the foreign direct investor (World } \\
\text { Investment Report 1999, United Nations) } \\
\text { Gross Domestic Product (GDP) is the sum of gross value added by all } \\
\text { resident producers in the economy plus any product taxes and minus any } \\
\text { subsidies not included in the value of the products. Dollar figures for GDP are } \\
\text { converted from domestic currencies using single year official exchange rates } \\
\text { (2001 World Development Indicators CD-ROM, World Bank) Exports of } \\
\text { goods and services represent the value of all goods and other market } \\
\text { services provided to the rest of the world. They include the value of } \\
\text { merchandise, freight, insurance, transport, travel, royalties, license fees, and } \\
\text { other services, such as communication, construction, financial, information, } \\
\text { business, personal, and government service (2001 World Development } \\
\text { Indicators CD-ROM, World Bank) }\end{array}$ \\
\hline $\begin{array}{l}\text { Economic } \\
\text { freedom }\end{array}$ & $\begin{array}{l}\text { The index of economic freedom (EFI) is based on objective components that } \\
\text { reflect the presence or absence of economic freedom. The ratings of four } \\
\text { components-tariffs, black market exchange premiums, capital market } \\
\text { restrictions, and the actual size of the trade sector relative to the expected- } \\
\text { are averaged to derive the index. Higher ratings are indicative of institutions } \\
\text { and policies more consistent with economic freedom (Economic Freedom of } \\
\text { the World: } 2001 \text { Annual Report, Cato Institute) }\end{array}$ \\
\hline Corruption & $\begin{array}{l}\text { Corruption Perceptions Index (CPI) ranks countries in terms of the degree to } \\
\text { which corruption is perceived to exist among public officials and politicians. It } \\
\text { is a composite index, drawing on } 14 \text { different polls and surveys from seven } \\
\text { independent institutions carried out among business people and country } \\
\text { analysts, including surveys of residents, both local and expatriate. } \\
\text { Transparency International (TI) focuses on corruption in the public sector and } \\
\text { defines corruption as the abuse of public office for private gain. The surveys } \\
\text { used in compiling the CPI tend to ask questions in line with the misuse of } \\
\text { public power for private benefits, with a focus, for example, on bribe taking by } \\
\text { public officials in public procurement. The CPI score relates to perceptions of } \\
\text { the degree of corruption as seen by business people, risk analysts, and the } \\
\text { general public, and ranges between } 10 \text {, highly clean, and } 0 \text {, highly corrupt. } \\
\text { For ease of interpretation, the rating was reversed with } 0 \text { indicating highly } \\
\text { clean and } 10 \text { highly corrupt (The Transparency International) }\end{array}$ \\
\hline $\begin{array}{l}\text { Human } \\
\text { development }\end{array}$ & $\begin{array}{l}\text { The human development index (HDI) is a measure of a country's } \\
\text { achievement based on three indicators: longevity, as measured by life } \\
\text { expectancy at birth; educational attainment, as measured by a combination } \\
\text { of adult literacy (two-thirds weight) and combined primary, secondary, and } \\
\text { tertiary enrollment ratios (one-third weight); and standard of living, as } \\
\text { measured by real GDP per capita (Human Development Report, United } \\
\text { Nations) }\end{array}$ \\
\hline
\end{tabular}

